\title{
First report of rust on Alnus in New Zealand is Melampsoridium betulinum, not $M$. hiratsukanum
}

\section{McKenzie EHC ${ }^{1 *}$, Padamsee $M^{1}$ and Dick $M^{2}$}

\author{
${ }^{1}$ Landcare Research, Private Bag 92170, Auckland 1142, New Zealand \\ ${ }^{2}$ Scion, Private Bag 3020, Rotorua 3046, New Zealand
}

McKenzie EHC, Padamsee M, Dick M 2013 - First report of rust on Alnus in New Zealand is Melampsoridium betulinum, not $M$. hiratsukanum. Plant Pathology \& Quarantine 3(2), 59-65, doi $10.5943 / \mathrm{ppq} / 3 / 2 / 1$

A rust disease was first observed in New Zealand on leaves of alder (Alnus viridis) in North Canterbury in 1980, then on Alnus spp. in Nelson in the 1990s and Auckland in 2012. The causal agent was determined by molecular techniques to be Melampsoridium betulinum and not $M$. hiratsukanum, a species that is currently spreading throughout the northern hemisphere. A rust on Betula nigra and B. populifolia, and earlier specimens from B. pendula, were also confirmed as $M$. betulinum.

Key words - Melampsoridium alni - pucciniales - rust fungi

Article Information

Received 20 May 2013

Accepted 10 June 2013

Published online 5 July 2013

*Corresponding author: Eric McKenzie - e-mail - mckenziee@landcareresearch.co.nz

\section{Introduction}

Three species of Melampsoridium infect alders (Alnus spp.): M. alni (Thüm.) Dietel, M. betulinum (Pers.) Kleb., and $M$. hiratsukanum S. Ito ex Hirats. f. (Hiratsuka et al. 1992). M. alni is restricted to East Asia and Siberia (Kaneko \& Hiratsuka 1981, Hantula et al. 2009). M. betulinum is widespread and occurs throughout New Zealand, but appears most common in the South Island. M. hiratsukanum, which probably originated in East Asia, is currently spreading throughout Europe.

Morphologically the three rusts are quite similar. However, urediniospores of $M$. alni have a single polar germ pore at either end, which distinguishes them from both $M$. betulinum and $M$. hiratsukanum, which have 2-3 germ pores near each end of the spore (Kaneko \& Hiratsuka 1981, Kurkela et al.
1999). There are small reported differences in the size of urediniospores of M. betulinum and M. hiratsukanum (Kurkela et al. 1999, Hantula et al. 2009), but these differences are, perhaps, insufficient to unequivocally distinguish the two species.

In June 2012 trees of Alnus cordata (Italian alder) growing on the Tamaki Campus, Auckland University, were noticed with abundant leaf spots (Fig. 1). Upon closer examination the spots were seen to contain uredinia of a rust fungus. Six weeks later another tree (Alnus sp.) in Mt Albert, Auckland was found with leaves covered in telia (Fig. 2); no uredinia were seen. Examination of leaves on the Tamaki trees one day later found a few telia scattered among the remaining uredinia. The heavy infection on the alders was suspected to be $M$. hiratsukanum. 
However, further investigation revealed that rust had been found earlier on Alnus spp. in New Zealand. In May 1980 rust had been observed on leaves of $A$. viridis (green alder) at the then Forest Research Institute nursery in North Canterbury (NZFRI specimen). Light infection of the rust was seen subsequently on other species of Alnus in the nursery. Information was later obtained about rust on Alnus spp. in Appletons Tree Nursery, Wakefield, Nelson (Eric Appleton, pers. comm.), where rust had been present on Alnus spp. for several years. In April 2013, seedlings of $A$. cordata in Appletons Nursery were heavily infected and their leaves were starting to fall whereas normally they remained attached until mid to late June depending on intensity of frosts; a 20-year old shelter belt of A. cordata was showing rust infection; seedlings of A. glutinosa (black alder, European alder) were almost bare due to heavy rust infection; the top leaves of A. glutinosa subsp. barbata (bearded alder) were infected but not falling; and A. rubra (red alder) had a small amount of rust on the lower leaves. Interestingly, plants of $A$. cremastogyna, $A$. firma, A. ?formosana, A. jorullensis, A. nitida and $A$. subcordata were rust-free, although light infection had appeared by mid May 2013 on A. ?formosana, A. nitida and A. subcordata.

Melampsoridium betulinum was known only on silver birch (Betula pendula) in New Zealand and was first recorded in the country by Robinson (1919). During an Auckland BioBlitz (late March 2012), a severe rust infection was noticed on leaves of Betula nigra (river birch, black birch) growing in the Auckland Botanic Gardens (Fig. 3). In Appletons Nursery, B. nigra, B. pendula and $B$. populifolia were all infected with rust in April 2013; the latter had shown infection for at least 10 years (Eric Appleton, pers. comm.). Some species appear to have remained rust-free including several Asiatic Betula spp. and a 35year-old Alnus nepalensis tree.

To determine the species of rust present on alders and birches in New Zealand, samples from New Zealand and from Europe were examined by both morphological and molecular methods.

\section{Methods}

\section{Isolates and morphology}

For examination of morphological features the rusts were mounted in lactophenol and examined with an Olympus BH-2 microscope. Voucher materials were deposited in the PDD fungarium. Specimens were also borrowed from the Finnish Forest Research Institute, Finnish Museum of Natural History.

\section{Phylogenetic analyses}

The rust fungi were also examined by molecular methods. Sori were excised and DNA was extracted using an X-tractor Gene System (Corbett Life Science, NSW, Australia). The nuclear ribosomal large subunit (LSU) locus was amplified with a rust-specific primer Rust2inv (Aime 2006) and LR6 (Vilgalys \& Hester 1990). The nuclear ribosomal internal spacer region (ITS) locus was amplified with ITS1F and ITS 4B (Gardes $\&$ Bruns 1993). ITS sequences generated were aligned with GenBank sequences of $M$. alni, $M$. betulinum, and $M$. hiratsukanum generated for two previous studies (Kurkela et al. 1999, Hantula et al. 2009). Phylogenies resulting from analyses of the LSU and ITS datasets were examined to identify any regions of conflict before concatenating the datasets in Geneious Pro v6.0.5 (Biomatters, http://www. geneious.com/). The concatenated dataset was analysed in PhyML 3.0 (Guindon \& Gascuel 2003) using the GTR $+\Gamma+\mathrm{I}$ model of evolution and 1,000 bootstrap support values were generated.

\section{Results}

\section{Morphological examination}

On Alnus spp. symptoms consisted of numerous orange uredinia on the lower leaf surface with a corresponding yellow-brown spot on the upper surface. The uredinia were covered by the epidermis, which eventually ruptured at a central pore. The sori were $<0.5$ $\mathrm{mm}$ diam., irregular in shape due to being restricted by the veins, scattered or in groups, covering large portions of the leaf. Uredinia possess a peridium with ovate-conical ostiolar 


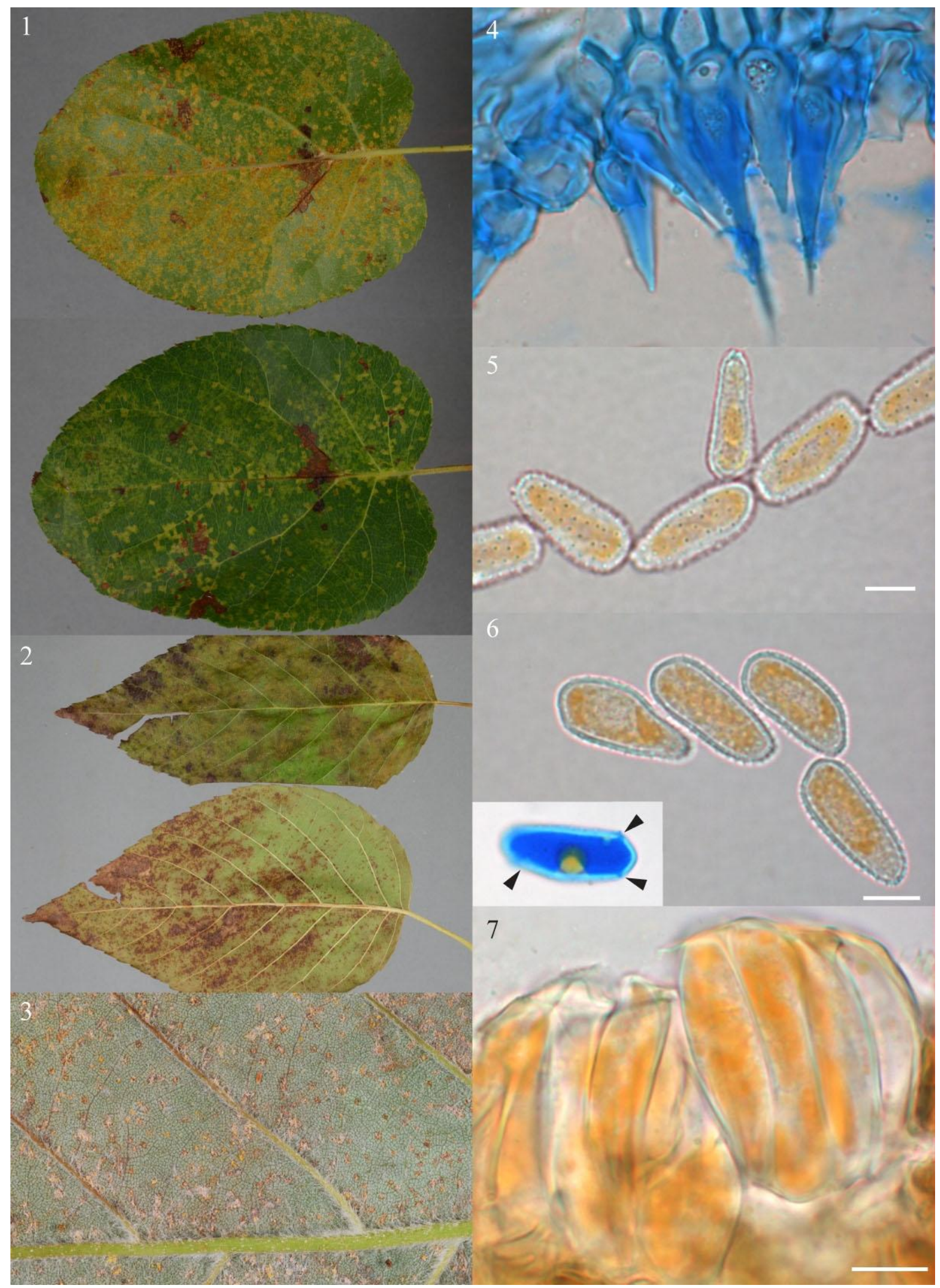

Figs 1-7 - Melampsoridium betulinum 1 Symptoms of uredinial infection on leaves of Alnus cordata. 2 Symptoms of telial infection on leaves of Alnus sp. 3 Symptoms of uredinial infection on leaves of Betula nigra. 4 Ostiolar cells in uredinia, tapering to a long acute apex. 5-6 Urediniospores; some are in a chain. Insert shows germ pores (arrowed). 7 Teliospores.

cells, 30-53 $\mu \mathrm{m}$ long, tapering to a long acute apex (Fig. 4). Urediniospores (Fig. 5, 6) were ellipsoidal to ovoid, usually broadly rounded at apex, obtusely rounded or angular at base, sometimes adhering in chains. They measured (23-)25-30(-33) × (9-)11-13(-16) $\mu \mathrm{m}(\mathrm{av}$. 
$27.7 \times 12.1 \mu \mathrm{m})$, with orange contents. The wall was thin, (0.5-)1-1.5 $\mu \mathrm{m}$, hyaline, and echinulate. The broad end of the spore was often smooth (tonsure). Germ pores were obscure, but when stained and heated with aniline blue two pores were visible at either end of the spore (Fig. 6). Uredinia were eventually replaced by yellowish brown, subepidermal telia, which later became darker in colour. Telia were confined to the lower leaf surface, with a brown spot on the corresponding upper surface. They were $<0.5$ $\mathrm{mm}$ diam., irregular in shape due to restriction by the veins, scattered or in groups, covering large portions of leaf. Teliospores (Fig. 7) were compacted laterally in a single layer beneath the epidermis, prismatic, cylindrical or elongate-clavate, sometimes inequilateral in shape, obtusely rounded at each end, sessile, and non-septate. They measured (27.5-)33$45(-55) \times(9-) 11-15.5(-17.5) \mu \mathrm{m}$ (av. $40.5 \times$ $12.7 \mu \mathrm{m})$, with pale yellow-brown contents. The wall was smooth, pale yellow-brown, 0.5$1.25 \mu \mathrm{m}$ thick at the sides and $1.5-3 \mu \mathrm{m}$ at apex.

Urediniospores were measured from 14 New Zealand specimens. Those from several Alnus spp. averaged $27.7 \times 12.1 \mu \mathrm{m}$, while those from Betula spp. averaged $29.1 \times 12.0$ $\mu \mathrm{m}$ (Table 1).

\section{Phylogenetic analyses}

The DNA sequences generated for this study have been deposited in GenBank under accession numbers KF031533-KF031565. Molecular analyses (Fig. 8) confirmed the New Zealand rust on both Alnus spp. and Betula spp. is $M$. betulinum and not M. hiratsukanum (TreeBASE accession number 14290, (http://purl.org/phylo/treebase/phylows/study/T B2:S14290)).-

Specimens examined - II indicates the presence of uredinia and III the presence of telia.

Melampsoridium alni - Russia, Khabarovskii krai, Ulchskii region, on $A$. mandshurica, 7 September 1976, Pentti Alanko 31971 (H 7019539-II).

Melampsoridium betulinum - New Zealand, Auckland, Auckland University,
Tamaki Campus, on Alnus cordata, 21 June 2012, E.H.C. McKenzie (PDD 102645-II); ibid., 5 August 2012 (PDD 102945-II, III); Mt Albert, on Alnus sp., 4 August 2012, E.H.C. McKenzie \& F.A. McKenzie (PDD 102647III); Manurewa, Auckland Botanic Gardens, on Betula nigra, 30 March 2012, E.H.C. McKenzie (PDD 102445-II). Nelson, Wakefield, Appletons Tree Nursery, on A. oblongata, 24 May 1998, E. Appleton (NZFRIM 3834-II); ibid., on A. glutinosa, March 2013 (PDD 103306-II); ibid., on A. acuminata ×glutinosa, 23 April 2013 (PDD 103310-II); ibid., on A. cordata (PDD 103307-II); ibid., on A. glutinosa subsp. barbata (PDD 103309-II); ibid., on A. rubra (PDD 103308-II); ibid., on B. nigra (PDD 103312-II); ibid., on B. pendula (PDD 103311-II); ibid., on B. populifolia, 30 April 2013 (PDD 103316-II); ibid., on A. ?formosana 22 May 2013 (PDD 103397-II); ibid., on A. nitida (PDD 103399-II); ibid., on A. subcordata (PDD 103398-II). North Canterbury, Rangiora, Forest Research Institute Nursery, on A. viridis, 21 May 1980, C.W. Barr (NZFRI-M 1893-II). Mid Canterbury, Christchurch, Addington, on $B$. pendula, 8 May 1995, A.J. Healy 95/60 (PDD 64927). Austria, Steiermark, Gurtaler Alpen, on B. nana, 6 September 2001, E. Teppner, H. Teppner (PDD 77196). China, Xinjiang, Gongliu, on B. pendula, 28 August 1986, Zhuang Jian-yun (PDD 59034). Finland, Helsinki, Kumpula, New Botanical Garden, on B. pendula, 9 October 2009, Pentii Alanko 143861 (H 6035396-II); Kuusamo, Oulanka, Biological Station, on B. pubescens, 7 August 2009, Pentti Alanko 142093 (H $6035417-$ II).

\section{Melampsoridium hiratsukanum}

Austria, Steiermark, Grazer, on A. pubescens, 19 September 2002, C. Scheuer, C.M. Denchev (PDD 77191); Steiermark, Schladminger Tauern, on A. incana, 5 August 2003, H. Riegler-Hager, Ch. Scheuer (PDD 78493). Finland, Kuhmo, Jauhovaara, on A. incana, 10 September 1998, Timo Kurkela (PDD 102745II); Helsinki, Vuosaari, on A. incana, 2 September 1998, Veikko Hintikka (PDD 102747-II); Varsinais-Suomi, Lohja, Sammatti, Luskala, on A. incana, 23 


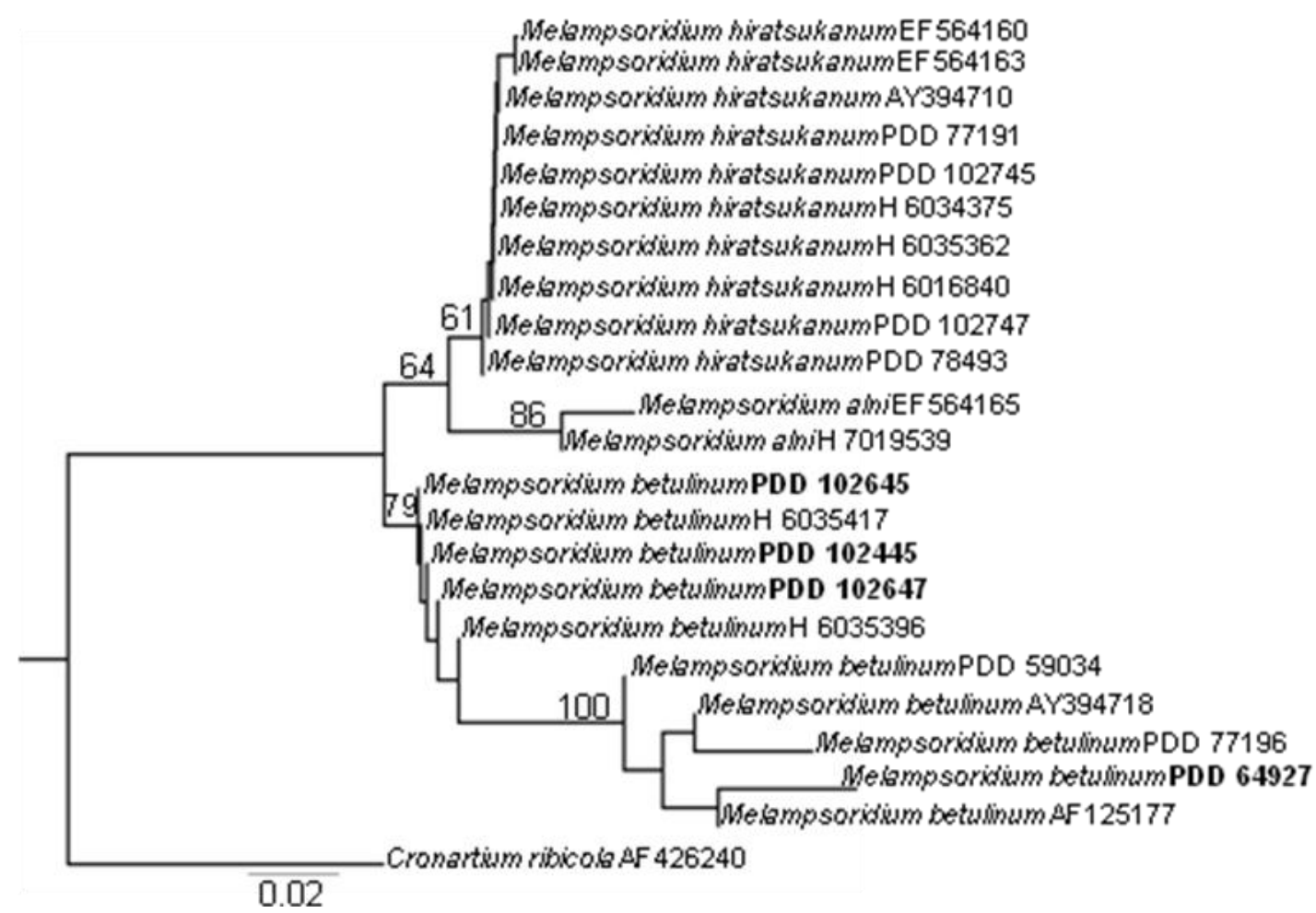

Fig. 8 - Phylogenetic tree based on maximum likelihood analyses of LSU and ITS sequences of multiple collections of Melampsoridium, and rooted with Cronartium ribicola, identified by either GenBank or fungarium accession numbers. Origins of sequences are provided in the text; those in bold are from New Zealand material. Numbers above branches indicate maximum likelihood bootstrap support (1000 replicates). Branch lengths are ML estimates and are scaled in terms of number of nucleotide substitutions per site.

Table 1 Dimensions of urediniospores of New Zealand collections of Melampsoridium betulinum

\begin{tabular}{|c|c|c|c|c|c|c|c|}
\hline \multirow[b]{2}{*}{ Host } & \multirow[b]{2}{*}{ PDD Nos } & \multicolumn{2}{|c|}{$\begin{array}{c}\text { Urediniospores } \\
\text { Length }(\mu \mathrm{m})\end{array}$} & \multicolumn{3}{|c|}{ Width $(\mu \mathrm{m})$} & \multirow[b]{2}{*}{ Maximum } \\
\hline & & Minimum & Mean & Maximum & Minimum & Mean & \\
\hline A. rubra & 103308 & 23.8 & 26.5 & 31.0 & 10.7 & 12.9 & 16.0 \\
\hline $\begin{array}{l}\text { A. acuminata } \\
\times \text { glutinosa }\end{array}$ & 103310 & 23.0 & 27.2 & 32.9 & 10.3 & 12.0 & 13.6 \\
\hline A. glutinosa & 103306 & 24.1 & 27.2 & 32.0 & 9.3 & 11.8 & 14.2 \\
\hline A. viridis & $1893 *$ & 24.1 & 27.2 & 33.4 & 10.1 & 12.2 & 14.6 \\
\hline B. nigra & 102445 & 23.3 & 27.5 & 32.0 & 9.6 & 11.7 & 13.3 \\
\hline B. nigra & 103312 & 22.5 & 27.7 & 34.2 & 10.0 & 12.3 & 14.7 \\
\hline B. pendula & 103311 & 24.1 & 27.8 & 30.4 & 8.2 & 10.7 & 13.4 \\
\hline A. cordata & 102645 & 25.2 & 28.4 & 33.2 & 9.1 & 10.6 & 16.0 \\
\hline A. cordata & 103307 & 22.7 & 28.6 & 32.1 & 10.7 & 12.5 & 14.7 \\
\hline $\begin{array}{l}\text { A.glutinosa } \\
\quad \text { ssp. barbata }\end{array}$ & 103309 & 24.6 & 28.8 & 33.7 & 10.9 & 12.5 & 14.3 \\
\hline B. pendula & 64927 & 23.6 & 29.4 & 36.9 & 10.9 & 12.4 & 14.7 \\
\hline B. populifolia & 103316 & 26.9 & 30.0 & 33.5 & 9.7 & 11.5 & 13.4 \\
\hline B. pendula & 46735 & 25.9 & 30.6 & 34.2 & 10.0 & 11.9 & 13.5 \\
\hline B. pendula & 45055 & 26.3 & 30.7 & 37.2 & 10.3 & 13.4 & 17.4 \\
\hline Alnus (av.) & & 23.9 & 27.7 & 32.6 & 10.2 & 12.1 & 14.8 \\
\hline Betula (av.) & & 24.7 & 29.1 & 34.1 & 9.8 & 12.0 & 14.3 \\
\hline
\end{tabular}

*NZFRI-M 
September 2009, Teuvo Ahti 69285 (H 6016840-II); Asikkala, Mustjärvi, Lyytikkä, on A. incana, 19 September 2012, Veli Haikonen 29109 (H 6034375-II); Sastamala, Suodenniemi, Torisevanmaa, on A. incana, 6 September 2009, Pentti Alanko 142823 (H 6035362-II).

\section{Forest Health database record Melampsoridium betulinum - New}

Zealand, North Canterbury, Eyreton, on $A$. rubra, 19 May 1982.

\section{Discussion}

When rust was observed on Alnus in New Zealand in 2012 it was suspected to be $M$. hiratsukanum. This species was described from Japan and is also known in other parts of Asia (China, Korea, Philippines). It also occurs in Central and South America (Argentina, Colombia, Costa Rica, Ecuador, Guatemala) (Farr \& Rossman 2013). It was found in Europe (Estonia, Finland) in mid 1990s and later confirmed as the cause of an epidemic outbreak of rust on Alnus spp. in Europe (Kurkela et al. 1999, Hantula et al. 2009). The rust is continuing to spread throughout Europe (e.g., Sert \& Sumbul 2005, Moricca \& Maresi 2010), and most recently was reported from Wales, and also British Columbia, western Canada (Hantula et al. 2012). Based on analyses of ITS sequences, Hantula et al. (2009) confirmed that the epidemic in Europe had its origins in eastern Asia. They suggested that the introduction of $M$. hiratsukanum into Europe may be due to natural migration, however, Hantula \& Scholler (2006) thought that introduction via contaminated plant material was most likely.

There are reported differences in the size of urediniospores of $M$. betulinum and $M$. hiratsukanum. Kurkela et al. (1999) found that in Finland and Estonia M. betulinum, collected from birch, had significantly longer urediniospores than $M$. hiratsukanum collected from alder (mean $31.6 \mu \mathrm{m}$ on $B$. pendula and $33.6 \mu \mathrm{m}$ on $B$. incana, versus $25.0 \mu \mathrm{m}$ on $A$. incana and $26.6 \mu \mathrm{m}$ on $A$. glutinosa). Similarly, Hantula et al. (2009) found that urediniospores of $M$. hiratsukanum averaged $26.0 \times 13.5 \mathrm{um}$, whereas urediniospores determined as $M$. betulinum from A. glutinosa and $A$. incana collected in Scotland were longer $(30.9 \times 13.4 \mu \mathrm{m})$, as were those from $B$. pendula and $B$. pubescens $(33.0 \times 14.7 \mu \mathrm{m})$ from Finland. The New Zealand specimens averaged $29.1 \times 12.0 \mu \mathrm{m}$ (from Betula spp.), and $27.7 \times 12.1 \mu \mathrm{m}$ (from Alnus spp.), both length measurements lying between those reported for $M$. hiratsukanum and $M$. betulinum (Kurkela et al. 1999, Hantula et al. 2009).

Two features seen in the New Zealand collections correspond with those described for M. hiratsukanum by Moricca \& Maresi (2010). Firstly, the urediniospores were sometimes in chains. Secondly, Moricca \& Maresi (2010) figured long tapering ostiolar cells, which were also noted in the New Zealand collections. However, the tapering ostiolar cells seem to be a feature of both $M$. betulinum and $M$. hiratsukanum (Wilson \& Henderson 1966, Hiratsuka et al. 1992).

Maximum likelihood analysis resulted in a phylogeny that recovered the same arrangement of Melampsoridium species as presented in Hantula et al. (2009) and confirmed that the rust on both Alnus and Betula in New Zealand is M. betulinum. There is a highly supported subclade (100\% ML bootstrap) consisting of five collections from Austria, China, Finland, Scotland, and New Zealand within the M. betulinum clade (Fig. 8). The percentage of sequence identity between these and the sequence of $M$ betulinum from Finland (H 6035396) range between 95.6$99.8 \%$. Further investigation using a different gene region is needed to determine if this subclade represents a distinct lineage. There were no obvious morphological differences between the urediniospores of the collections within the M. betulinum clade.

This is not the first recorded instance of M. betulinum on alders. In Scotland, an endemic rust indistinguishable from $M$. betulinum occurs on alders (A. glutinosa, A. incana), whereas alders in areas of Europe affected by the current epidemic are infected by $M$. hiratsukanum (Hantula et al. 2009). Melampsoridium hiratsukanum infects a broad range of Alnus spp. and in Europe is common on A. glutinosa and A. incana (Hiratsuka et al. 1992, Hantula et al. 2009, Farr \& Rossman 2013). Both $M$. hiratsukanum and $M$. 
betulinum have an alternate host (Larix spp.) on which their aecial stages occur (Hiratsuka et al. 1992, Farr \& Rossman 2013). M. hiratsukanum from naturally infected alder in Finland produced aecia on all Larix species tested but did not infect Betula (Hantula et al. 2009). Neither pycnia nor aecia are known for $M$. betulinum in New Zealand.

This is the first report of $M$. betulinum in New Zealand on Alnus spp. and on Betula nigra and B. populifolia.

\section{Acknowledgements}

This research was supported through the Landcare Research Systematics Portfolio, with funding from the Science and Innovation Group of the New Zealand Ministry of Business, Innovation and Employment. Stephan Helfer (Royal Botanic Gardens, Edinburgh), Timo Kurkela (Finnish Forest Research Institute), and Pertti Salo (Finnish Museum of Natural History) kindly provided specimens of Melampsoridium spp. from Europe. Eric Appleton and Peter Gadgil kindly provided specimens of $M$. betulinum from New Zealand.

\section{References}

Aime MC 2006 - Toward resolving familylevel relationships in rust fungi (Uredinales). Mycoscience 47, 112-122.

Farr DF, Rossman AY 2013 - Fungal Databases, Systematic Mycology and Microbiology Laboratory, ARS, USDA. Retrieved 24 April 2013, from http://nt.ars-grin.gov/fungaldatabases/

Gardes M, Bruns TD 1993 - ITS primers with enhanced specificity for basidiomycetes ---_application to the identification of mycorrhizae and rusts. Molecular Ecology 2, 113-118.

Guindon S, Gascuel O 2003 - A simple, fast, and accurate algorithm to estimate large phylogenies by maximum likelihood. Systematic Biology 52, 696-704.

Hantula J, Scholler M 2006 - NOBANIS Invasive alien species fact sheet.
Melampsoridium hiratsukanum. Retrieved 24 April 2013, from www.nobanis.org

Hantula J, Kurkela T, Hendry S, Yamaguchi T 2009 - Morphological measurements and ITS sequences show that the new alder rust in Europe is conspecific with Melampsoridium hiratsukanum in eastern Asia. Mycologia 101, 622-631.

Hantula J, Nigel Stringer R, Lilja A, Kurkela T 2012 - Alder rust, Melampsoridium hiratsukanum Ito, identified from Wales, UK and British Columbia, Canada. Forest Pathology 42, 348-350.

Hiratsuka N, Sato S, Katsuya K, Kakishima M, Hiratsuka Y, Kaneko S, Ono Y, Sato T, Harada Y, Hiratsuka T, Nakayama K 1992 - The rust flora of Japan. Tsukuba Shuppankai, Takezono, Ibaraki. 1205 p.

Kaneko S, Hiratsuka N 1981 - Classification of the Melampsoridium species based on the position of urediniospore germ pores. Transactions of the Mycological Society of Japan 22, 463-473 (In Japanese).

Kurkela T, Hanso M, Hantula J 1999 Differentiating characteristics between Melampsoridium rusts infecting birch and alder leaves. Mycologia 91, 987992.

Moricca S, Maresi G 2010 - Melampsoridium hiratsukanum reported for the first time on grey alder in Italy. New Disease Report 21, 17.

Robinson RG. 1919 - Diseases in plantations of exotic trees. New Zealand Journal of Agriculture 18, 63.

Sert H, Sumbul H 2005 - First report of Melampsoridium hiratsukanum infecting alder (Alnus orientalis var. orientalis) in Turkey. Plant Pathology 54, 241.

Vilgalys R, Hester M 1990 - Rapid genetic identification and mapping of enzymatically amplified ribosomal DNA from several Cryptococcus species. Journal of Bacteriology 172, 4238-4246.

Wilson M, Henderson DM 1966 - British rust fungi. University Press, Cambridge. 384 p. 